\title{
Intergenerational gap dynamics
}

\author{
Madalina Mirela RADULESCU \\ The Bucharest University of Economic Studies, Bucharest, Romania \\ madalina.radulescu@fun-training.ro \\ Valentina Mihaela GHINEA \\ The Bucharest University of Economic Studies, Bucharest, Romania \\ valentina_ghinea@yahoo.com \\ Ramona CANTARAGIU \\ The Bucharest University of Economic Studies, Bucharest, Romania \\ ramona_cantaragiu@yahoo.com
}

\begin{abstract}
Diversity, sustainability and change are words nowadays commonly encountered in business practice and theory. Businesses face multiple challenges in regards to complexity, innovation, creativity, digitalization and out of the box thinking. However, what underlies these challenges is dealing with a very diverse workforce comprised of multiple generations with very different takes in regards to employment, career development, team work, authority and many other organizational aspects. Basically, business continuity nowadays depends in a large degree on the ability to manage the workforce comprised of employees belonging to the Silents, the Baby Boomers, Generation X and Generation Y, and to prepare for the entrance on the labor market of Generation $Z$, the first generation that grew up in the digital world. Classification into generations is not without its contestations, but it continues nonetheless to be an important determinant of the way in which businesses design their human resources strategies. Based on a quantitative survey of the opinions of employees from various backgrounds in regards to intergenerational dynamics and conflicts, the present research uncovers the relevancy of the classification into generations for the human resources practices. The research also provides an insight into the main challenges that arise from the existence of differences in the points of view of these four main generations and concludes with a series of recommendations for human resources managers and leaders in general. The article's innovativeness lies in the fact that it emphasizes the need for the development of human resources strategies which take in consideration all the generations in an equal manner, thus criticizing the current trends in human resources practice which rely on the development of programs specifically targeted to certain generations.
\end{abstract}

Keywords: complexity, generational theory, generational dynamics, human resource strategy, inclusive environment.

\section{Introduction}

It seems that finding methods to maximize the performance of every employee has never been more important than today. To succeed, no matter the field of activity, companies need dedicated or at least engaged employees. As nowadays an increasingly large part of the corporate labor force is occupied by Generation Y (i.e., the Millennials), a lot of companies manifest a sense of urgency in finding ways to effectively adapt to the high expectations and requirements of this generation.

Therefore, it seems logical for companies to prepare themselves and adjust their human resources policies and practices in order to adapt to this new generation which has higher career aspirations, different attitudes concerning the workplace and greater knowledge of the latest technologies in comparison to previous generations. More and more frequently, we hear voices advocating for the change of organizational culture of today's companies in accordance with the Millennials' different habits and attitudes, and 
this need is sustained by statistics which show that the proportion of Millennial employees is rapidly increasing (Table 1 ).

Table 1. US labor force demographic data, 2006-2011

\begin{tabular}{|l|c|c|}
\hline \multirow{2}{*}{} & \multicolumn{2}{|c|}{ Workforce participation (\%) } \\
\cline { 2 - 3 } & $\mathbf{2 0 0 6}$ & $\mathbf{2 0 1 1}$ \\
\hline Silentgeneration (before 1945) & 8 & 5 \\
\hline Baby Boom generation (1946- 1964) & 44 & 38 \\
\hline Generation X (1965 - 1980) & 33 & 32 \\
\hline Generation Y (1981- 200) & $15 \quad 25$ \\
\hline
\end{tabular}

Blinded by the urgency of daily issues, few are those who remain calm and therefore able to thoroughly analyze the reality at a macro scale, understand its prerequisites and also to foresee the problems that we actually cause by our very actions. Looking behind, we can identify the social, economic and environmental factors which have increased life expectancy and enabled us to work for a longer period of time. Although we are more numerous and we live longer, this does not necessary mean that we are also all enjoying a healthier life. In fact, we live longer rather than healthier. We are more educated, as access to education is encouraged, but the quantity and quality of our knowledge, when talking about huge masses of people, shows a dilution trend (Wongupparaj et al., 2017), and nevertheless a gradual but continuous change in the areas of interest (Pagar et al., 2017). The successful patterns met on the labor market swing between the adaptable employee and the highly specialized one (Mikhalevich et al., 2017), whereas in terms of behavior, we equally praise and look down on both workaholic obedience and naughty intelligence.

In this context, it is arguably questionable to discuss about global trends in regards to human profiles and to classify people into different generations based solely on their date of birth. How relevant is this delimitation when considering the differences between those people who live in rural areas versus urban areas or between lower classes and middle classes? How did people from developed urban zones, dominated by mass media and the latest technological developments become the representatives for the entire human race, even for those without television and Internet in the discussion about the current workforce?

An Arab proverb says that "People resemble their times more than they resemble their parents." Considering this point of view, delimiting groups of people function of the time span that they go through seems rightful. A generation is represented by the people who were born at the same time and have experienced the same historical conditions (AARP, 2007). These conditions refer to ideas about what is right or wrong, good or bad, stylish or unstylish, heroes or villains, preferable behaviors in regards to parenting, communication, past time activities etc. which make people from a generation share the same tastes and moods. There are numerous studies which show that individual behavior is shaped by the socio-cultural environment in which the individual is born and raised in, as well as by the individual's experience, including education (Avolio and Gardner, 2005; Popper and Mayseless, 2007). Certain scholars argue that life experiences influence the way in which individuals view the world and that free will is a far better predictor of individual behavior than environmental conditioning (Xenakis, 2010), but it is generally accepted that some common perspectives on critical issues 
such as communication, problem solving, decision making and even leadership are indeed shared by people from the same generation (Long Standifer, 2017).

In the end, classifying people into generations based on certain common general characteristics is not a problem in itself. But the fact that on the labour market one can nowadays find four different generations, can constitute a difficult situation for the HR specialists. Thus, managing age diversity turns into managing generational diversity, which proves to be no longer just a fancy concept, but a harsh reality with real consequences. Yet, focusing only on how to address the youngest generation, the Millennials, which is just a part of the labour force, might lead to discrepancies and accentuate the gap between co-workers. This is why companies are challenged to find the most adequate way of managing the different views and needs of the four generations, the so-called Silent, Baby Boomers, Generation X and Generation Y. Although intergenerational differences were traditionally perceived as normal, the latest HR trends seek to manage these differences in order to ensure that generation are able to effectively work tougher, leading to a series of highly controversial HR strategies.

\section{Intergenerational dynamics in the workplace}

The history of studies on generational dynamics began with Anthony F. C. Wallace (1956) who investigated how cultures deliberately change themselves and display a recurrent pattern in their social movements. Later on, his work was continued by William G. McLoughlin (1978) who identified five awakenings (periods of revitalization brought about times of cultural stress which end in drastic social reform) in the AngloAmerican history. He saw these awakenings as means of creating and sustaining the nations' identities in a changing world.

Then in the '80s, the historians William Strauss and Neil Howe deepened the previous researches and filled in the missing details between an awakening to a crisis war and further to an awakening and another crisis war (Xenakis, 2010). They considered society similar to a living organism, continuously evolving because of the different generational personae coming together and forming it, as old generations pass away and new ones emerge. Moreover, Howe and Strauss (2007, p. 42) found that "generations shaped by similar early-life experiences often develop similar collective personae and follow similar life trajectories. The patterns are strong enough to support a measure of predictability." However, this does not apply to one single individual, not even a small group, given the strong manifestation of free will and of personal circumstances. On the contrary, huge masses of people tend to display similar attitudes and behaviors following some patterns throughout time. These are pretty much obvious related to gender and family issues, risk aversion, political perspectives, and levels of xenophobia. Howe and Strauss (2007), in their study of the Anglo-American history since the War of the Roses in the late 1400s until now, identified a regular succession of four archetypes, namely the Prophet, Nomad, Hero and the Artist. From their point of view, no matter how fanciful the name of the generation is, they all come down to the same basic features embedded into the above-mentioned ones. They also argue that it is not only a matter of horizontal generational change (as in a historical succession), but also about vertical diversity during a life span of the same generation, as people composing a generation change as they age. Hence the result is a generational matrix (Figure 1). 


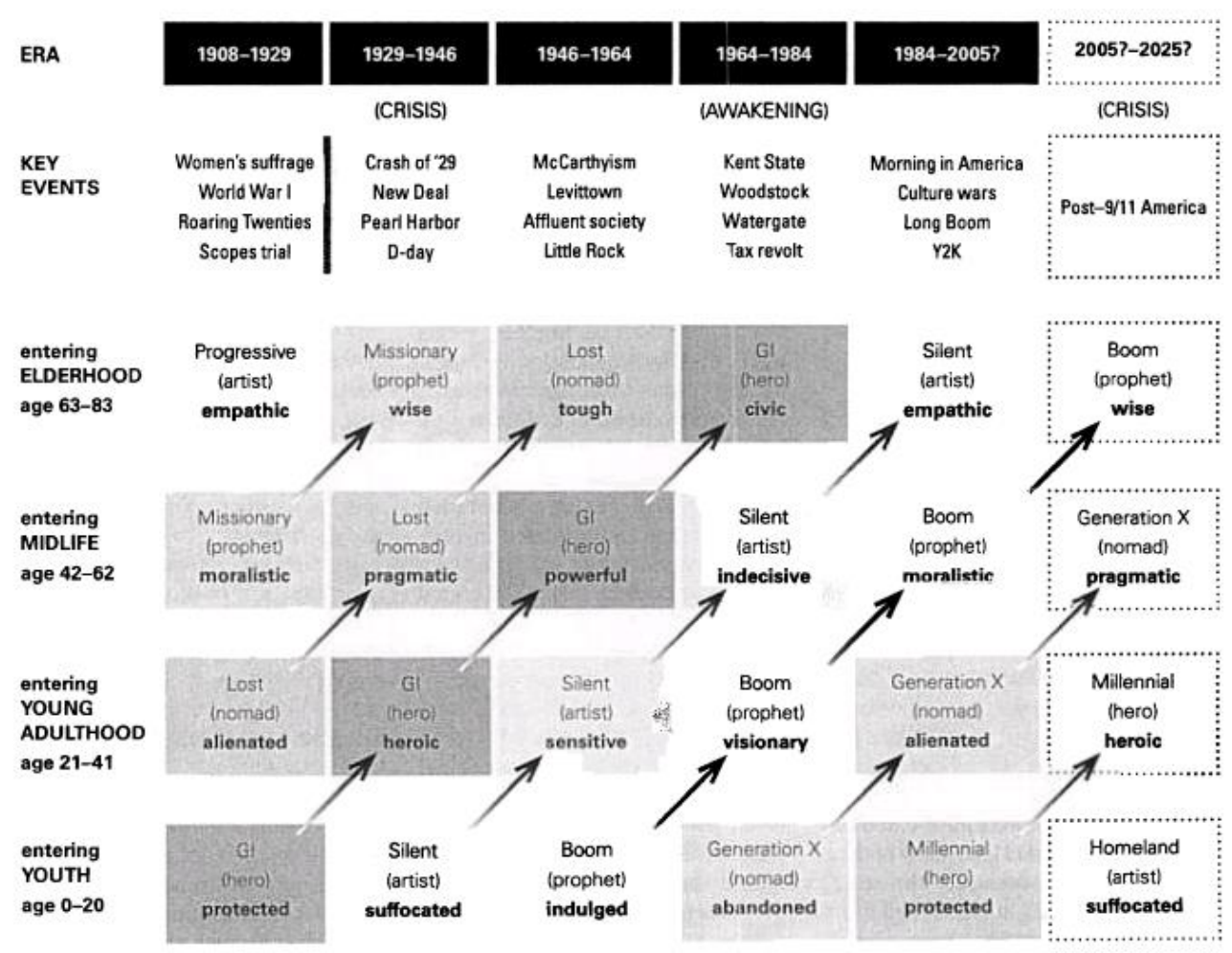

Figure 1. Generational matrix

PICBE | 832

Source: Howe and Strauss (2007).

As they age, each archetype radically changes the attitude and behavior, this being also in accordance with the human psychological evolution (Howe and Strauss, 2007; Barrett, 2014). Therefore, during the entering youth age bracket, the Hero archetype grows up as a protected child, then in the young adulthood age bracket becomes alienated, during midlife starts emphasizing moralistic behavior, and after entering elderhood becomes emphatic. The Artist archetype starts life as an overprotected and suffocated child, comes at the age of young adulthood as a heroic character, turns into a pragmatic midlife individual, and finally behaves as a wise individual when reaching old age. The succession of two decades, in the Prophet archetype's case, is: indulged youth, sensitive young adult, powerful midlife, and tough elderhood, whereas the Nomad archetype goes from the unprotected childhood, even abandoned, to visionary adulthood, to the mellow and indecisive midlife, and ends with a period full of civic spirit.

Interesting as well is the fact that, besides the specific ageing process of each generation apart, there is also a trend in reproducing during young adulthood the main characteristics of the parents' generation, during midlife - the grandparents' generation and so on. Therefore, Howe and Strauss (2007, p. 42) consider that, by knowing the historical precedent, it is "possible to foresee how the generations alive today will think and act in decades to come". And this is exactly what generational dynamics does: it extends the two historians' generational theory by involving major theoretical extension and developing it into an interdisciplinary subject encompassing comparative history, mathematics, chaos theory, sociology, population dynamics, economics, macroeconomics, system dynamics, and even the theory of evolution (AARP, 2007; Xenakis, 2010). 
Coming back to the situation of the current generations which are concurrently found on the job market, Harrison (in Birkman (n.d.)) found that more than $60 \%$ of the employees report having experienced intergenerational conflicts. These conflicts are caused by the fact that generations have different perspectives when it comes to work ethic, leadership and authority. According to Kavros and Berger (2014), the common topics that trigger generational disputes within a team are related to: a. choosing when and where to work; b. communicating among team members; c. getting together; $d$. finding information; e. learning new things.

A review of the literature on generational differences points towards the fact that there are various aspects of human resources practices which are viewed entirely different by people belonging to different generations (see Table 2). These differences lead to concerns related to the way in which employees interact. For example, young employees when interacting with elder managers, are mostly concerned about: a. the latter resistance to change; b. parsimony in providing recognition; c. too much focus on micromanagement; $d$. too much consideration for the chain of command; e. low respect for the employees' work-life balance; f. inflexibility; g. unfair or excessive criticism; h. lack of understanding of the job reality (Society for Human Resource Management, 2011). However, for elder employees subordinated to a younger manager the main concerns are about: a. disrespect for the business attire; b. poor work ethic; c. informal language; d. behavior; e. necessity of being supervised; f. too much reliance on technology; g. disregard for the hierarchy; h. inability to balance work and life; i. inability to work within a defined structure (Society for Human Resource Management, 2011).

Table 2. Generational differences in regards to organizational aspects

\begin{tabular}{|c|c|c|c|c|}
\hline & Silents & Baby Boomers & Generation X & Generation $Y$ \\
\hline OUTLOOK & Practical & Optimistic & Skeptical & Hopeful \\
\hline WORK ETHIC & Dedicated & Driven & Balanced & Ambitious \\
\hline $\begin{array}{ll}\text { VIEW } & \text { OF } \\
\text { AUTHORITY } & \end{array}$ & Respectful & Love / hate & Unimpressed & Relaxed, polite \\
\hline LEADERSHIP BY & Hierarchy & Consensus & Competence & $\begin{array}{l}\text { Achievement, } \\
\text { pulling together }\end{array}$ \\
\hline RELATIONSHIPS & Self-sacrifice & $\begin{array}{l}\text { Personal } \\
\text { gratification }\end{array}$ & $\begin{array}{l}\text { Reluctance to } \\
\text { commit }\end{array}$ & Loyal, inclusive \\
\hline PERSPECTIVE & Civic-minded & Team-oriented & Self-reliant & Civic-minded \\
\hline TURN-OFFS & Vulgarity & $\begin{array}{l}\text { Political } \\
\text { incorrectness }\end{array}$ & Clichés, hype & $\begin{array}{l}\text { Cynicism, } \\
\text { condescension }\end{array}$ \\
\hline \multirow[t]{3}{*}{$\begin{array}{l}\text { COMMUNICATION } \\
\text { PREFERENCES }\end{array}$} & $\begin{array}{l}\text { Attitude = } \\
\text { respectful, good } \\
\text { grammar, clear } \\
\text { diction, no slang } \\
\text { or profanity }\end{array}$ & & & Attitude $=$ positive \\
\hline & $\begin{array}{l}\text { Language }=\text { formal } \\
\text { and professional }\end{array}$ & $\begin{array}{l}\text { Language = } \\
\text { informal = } \\
\text { conversation = } \\
\text { relational (over } \\
\text { coffee/lunch) }\end{array}$ & & $\begin{array}{l}\text { Language = no } \\
\text { condescension, } \\
\text { cynicism or } \\
\text { sarcasm }\end{array}$ \\
\hline & $\begin{array}{l}\text { Message = related } \\
\text { to company } \\
\text { history and long- } \\
\text { term goals }\end{array}$ & $\begin{array}{l}\text { Message = focus } \\
\text { on mutual } \\
\text { interests ("How is } \\
\text { your son doing in } \\
\text { college?") }\end{array}$ & $\begin{array}{l}\text { Message = clear, } \\
\text { direct, } \\
\text { straightforward, } \\
\text { no corporate- } \\
\text { speak (no waste of } \\
\text { time) }\end{array}$ & $\begin{array}{l}\text { Message }=\text { tied to } \\
\text { the personal/team } \\
\text { goals }\end{array}$ \\
\hline
\end{tabular}

DOI: 10.2478/picbe-2018-0074, pp. 829-842, ISSN 2558-9652| Proceedings of the $12^{\text {th }}$ International Conference on Business 


\begin{tabular}{|c|c|c|c|c|}
\hline & $\begin{array}{l}\text { Communication } \\
\text { channel = face-to- } \\
\text { face }\end{array}$ & $\begin{array}{l}\text { Communication } \\
\text { channel = face-to- } \\
\text { face }\end{array}$ & $\begin{array}{l}\text { Communication } \\
\text { channel = email / } \\
\text { voicemail (what, } \\
\text { why, when, } \\
\text { where) }\end{array}$ & $\begin{array}{l}\text { Communication } \\
\text { channel = text } \\
\text { message / face-to- } \\
\text { face }\end{array}$ \\
\hline $\begin{array}{l}\text { ORGANIZATIONAL } \\
\text { BEHAVIORS }\end{array}$ & $\begin{array}{l}\text {-disciplined } \\
\text {-loyal team } \\
\text { players } \\
\text {-respectful of } \\
\text { authority } \\
\text {-follow the rules } \\
\text {-patient } \\
\text {-vast knowledge } \\
\text { legacy to share } \\
\text {-work ethic }\end{array}$ & $\begin{array}{l}\text {-ambitious } \\
\text {-competitive } \\
\text {-focus on personal } \\
\text { accomplishments } \\
\text {-working long- } \\
\text { hours (expect the } \\
\text { same from } \\
\text { younger) } \\
\text {-comfortable with } \\
\text { the rules they } \\
\text { created }\end{array}$ & $\begin{array}{l}\text {-loyalty = } \\
\text { committed to } \\
\text { their work and } \\
\text { people they work } \\
\text { with, not to the } \\
\text { company } \\
\text {-skeptical } \\
\text {-risk-takers } \\
\text {-want fun in the } \\
\text { workplace } \\
\text {-seek work-life } \\
\text { balance }\end{array}$ & $\begin{array}{l}\text {-team-oriented } \\
\text {-tackling multiple } \\
\text { tasks with equal } \\
\text { energy } \\
\text {-having juggled } \\
\text { sports, school and } \\
\text { social interests }\end{array}$ \\
\hline $\begin{array}{l}\text { WORKPLACE } \\
\text { STRENGTHS }\end{array}$ & $\begin{array}{l}\text {-Hard-working } \\
\text {-Stable } \\
\text {-Loyal } \\
\text {-Thorough } \\
\text {-Detail oriented } \\
\text {-Focused } \\
\text {-Emotionally } \\
\text { mature }\end{array}$ & $\begin{array}{l}\text {-Team perspective } \\
\text {-Dedicated } \\
\text {-Experienced } \\
\text {-Knowledgeable } \\
\text {-Service-oriented }\end{array}$ & $\begin{array}{l}\text {-Independent } \\
\text {-Adaptable } \\
\text {-Creative } \\
\text {-Techno-literate } \\
\text {-Willing to } \\
\text { challenge status } \\
\text { quo }\end{array}$ & $\begin{array}{l}\text {-Optimistic } \\
\text {-Able to multitask } \\
\text {-Tenacious } \\
\text {-Technologically } \\
\text { savvy } \\
\text {-Driven to learn } \\
\text { and grow } \\
\text {-Team oriented }\end{array}$ \\
\hline $\begin{array}{l}\text { WORKPLACE } \\
\text { STRUGGLES }\end{array}$ & $\begin{array}{l}\text {-Reticent when } \\
\text { they disagree } \\
\text {-Respect for } \\
\text { diversity } \\
\text {-Reluctant to } \\
\text { buck the system } \\
\text {-Uncomfortable } \\
\text { with conflict } \\
\text {-Presenteeism } \\
\text { related to medical } \\
\text { issues } \\
\text {-Not as } \\
\text { comfortable with } \\
\text { technology }\end{array}$ & $\begin{array}{l}\text {-Nontraditional } \\
\text { work styles } \\
\text {-Sharing praise } \\
\text { and rewards } \\
\text {-Uncomfortable } \\
\text { with conflict, } \\
\text { reluctant to go } \\
\text { against peers } \\
\text {-Work-life balance } \\
\text {-Technology } \\
\text { replacing human } \\
\text { interaction }\end{array}$ & $\begin{array}{l}\text {-Career } \\
\text { development } \\
\text {-Conflict } \\
\text { resolution and } \\
\text { office politics } \\
\text {-Skeptical and } \\
\text { distrustful of } \\
\text { authority } \\
\text {-Multi- } \\
\text { generational team } \\
\text { projects } \\
\text {-Work-life balance }\end{array}$ & $\begin{array}{l}\text {-Respectful } \\
\text { communication } \\
\text {-Functional } \\
\text { literacy } \\
\text {-Need supervision } \\
\text { and structure } \\
\text {-Reject the } \\
\text { concept of "paying } \\
\text { dues" } \\
\text {-Expect input } \\
\text { immediately }\end{array}$ \\
\hline
\end{tabular}

Finally, Amour (2005) found that despite the fact that these differences trigger creativity, they also cause employees to experience a large amount of frustration and poor morale, thus jeopardizing business productivity, if they are misunderstood and not managed effectively. The prevalent view in the literature is that organizations have to find ways to harmonize the differences between generations in order to avoid the threat to sustainability generated by intergenerational conflicts. This means that organizations have to transform themselves into learning organizations which have the capacity to be agile and adjust to changes in the external and the internal environment. In order to achieve this agility, it is necessary for organizations to empower its workforce to think, to observe, to understand, to unlearn and then relearn, to challenge the status quo and innovate (McKenna and Beech, 2002). This is not possible if one generation is given priority over the others and when the dialogue between generations starts from the premise that intergenerational differences are insurmountable. 


\section{Research methodology}

The present study aims to better understand if there truly is an intergenerational gap, larger than before, and if this is turning into a major social problem, or if everything related to intergenerational gaps is just a fad in the human resources literature used as an excuse to turn our attention to the need to change traditional HR procedures. In order to achieve this goal, we surveyed the opinions of employees, irrespective of age or specialization, on the existence and manifestation of intergenerational gaps. In addition, the research also sought to find out the means through which we can navigate the complex relationships that our society presently exhibits.

There is no general agreement among researchers regarding the time when a generation began and the time it ended. We also consider that a generation cannot begin and end in a very precise day, therefore we conventionally agreed to refer to people born before 1955 as to the Silent, to those born between 1955 and 1969 as the Baby Boom Generation (49 to 63 years old), to those born between 1970 and 1988 as Generation X (30 to 48 years old), and to those born between 1989 and 2000 as Generation Y (18 to 29 years old). We went for this delimitation mainly considering the special circumstances that Romania has had to face in the past (i.e., the ban on abortions instituted in 1966 which made us extend the period of Baby Boomers with an additional 5 years) and the cultural differences which required us to make changes in the temporality of the generations.

The present study is a pilot one. It succeeded to gather a number of 56 respondents by means of convenient sampling. The questionnaire consisted of 22 questions, out of which 18 questions were closed-ended and the other four questions were open-ended. The responses were gathered online so the study targeted only the segment of population with access to the Internet.

\section{Research results}

In total we have analyzed a number of 56 responses, out of which 46 came from Romanian respondents. In terms of generational structure, we can observe a poor representation of the Baby Boomers (only 5.5\% responses), a prevalence of Generation $\mathrm{X}$ representatives (54.5\%), followed by Generation Y $(40 \%)$ and the lack of responses from the Silent Generation. These proportions are justified by the type of instrument used (online questionnaire) and the channel of communication used in assessing opinion (Facebook and other websites). It is acknowledged that the Silent Generation is not comfortable with technology, and Baby Boomers do not consent the replacement of human interaction by the technology. Whereas at the opposite pole, the other two generations are, if not technological savvy (Generation Y), at least techno-literate (Generation X).

Related to the job position, most of the respondents were part of the managerial staff $(43,6 \%)$, while $20 \%$ of the respondents were hired on technical positions, and the rest of $36,4 \%$ were regular employees (figure 2).

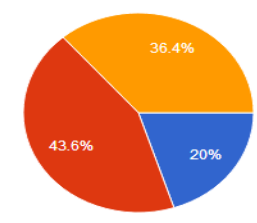

- technical position

- regular employee

Figure 2.Position held by the respondents

Source: Authors' own research results. 
As seen in the Figure 3, a quarter of the respondents (25.5\%) have been working at the current job for more than four and less than ten years, and another $23.6 \%$ reported less than one-year seniority. People who had reached more than ten years in the same workplace represented $21.8 \%$ of the sample. Out of these, $8.3 \%$ were Baby Boomers and $91.7 \%$ belonged to Generation X. At first glance, the predisposition towards loyalty and stability is obvious, as almost half of the respondents $(47.3 \%)$ had more than four years of seniority in the current organization.
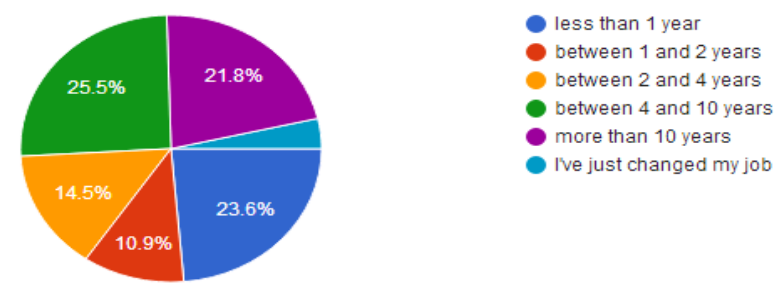

Figure 3.Seniority at the work place

Source: Authors' own research results.

Despite the general opinion that Millennials (Generation $Y$ ) is hard to understand, the study reveals that one quarter have not thought about this, while $26.8 \%$ see Baby Boomers as the most difficult generation to understand, and only $25 \%$ of the respondents point Generation Y (Figure 4). The majority of the respondents who reported that they have the most difficult time getting along with the Baby Boomer Generation belonged to Generation Y (57.1\%), while most of those who had issues with their relations with Generation Y belonged to Generation X (85.7\%). Surprisingly, Generation Y seems to be the most tolerant generation (50\%), closely followed by Generation X (42.9\%).

The explanations given by the neutral respondents comprised reasons such as: "It all depends on people not on age, differences do not seem to be relative to a generation", "I have worked with people between 18 and 50 years of age and I did not encounter any difficulties", etc.
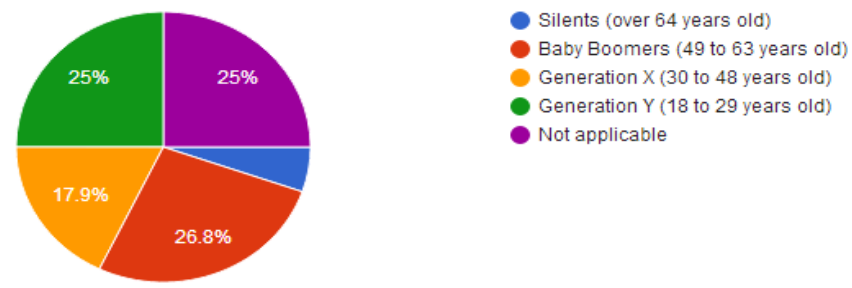

\section{Figure 4.The most difficult generation to interact with}

Source: Authors' own research results.

The ones who reported difficulties in working with other generations were highly concerned with the lack of tolerance and reluctance in accepting other perspectives and priorities (82.1\%), values (51.8\%), beliefs (62.5\%), and life styles (50\%). It is interesting that the same reasons are given by different generations. This confirms the idea of the evergreen conflict between generations, which is also sustained by the answers displayed by Figure 5a. However, there was no general agreement related to the amount of conflicts triggered by the so-called generation gap: while $33.9 \%$ of the respondents blamed disputes on age diversity, the majority (66.1\%) do not find a clear evidence of the influence of age differences or are not aware of this possibility (figure $5 b$.). 
The only particular explanation retrieved in the youngest generation defense is "the lack of openness of the other generations for using technology" (45\% of the answers provided by the Generation Y representatives).
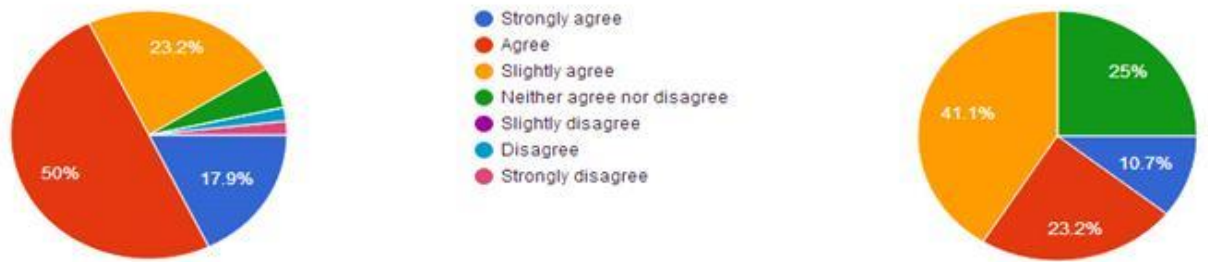

- More than $50 \%$

About $50 \%$

Less than $50 \%$

- I do not know

PICBE | 837

Figure 5a. The existence of intergenerational conflicts; $5 b$. Conflicts caused by or related to the so-called generation gap

Source: Authors' own research results.

The outcomes are rather different when considering difficulties in understanding customers from different generations (Figure 6). At this point only $12.5 \%$ consider that there is no reason to worry about. Generation $\mathrm{X}$ is generally perceived as the most difficult to understand (28.6\%), closely followed by Baby Boomers (25\%), while the Silent Generation was situated on the last position with only $14.3 \%$. Quite a surprise was the percentage assigned to Generation Y (19.6\%).
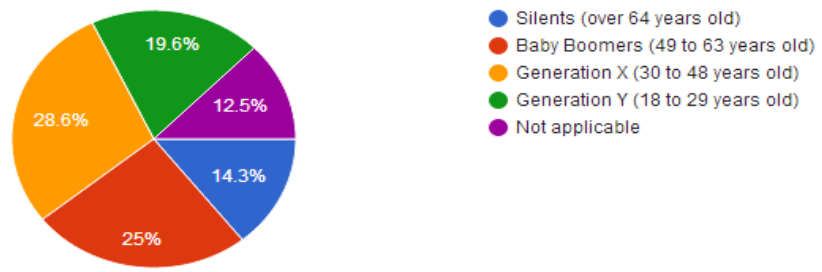

\section{Figure 6. The most difficult generation to please}

Source: Authors' own research results.

Most of the respondents (46.4\%) have difficulties understanding customers belonging to the next generation, while $16 \%$ have difficulties understanding customers from their own generation. Moreover, more than a half of the respondents (55.4\%) see the generation gap escalating into a major social problem (Figure 7). In regards to the type of problems caused be intergenerational gaps, respondents mentioned workrelated issues $(21.4 \%)$, motherhood, parenthood and relationship within the family (10.7\%), demographic issues (7.1\%), political crises (7.1\%), and inclusion (5.4\%). These are in accordance with the main areas identified for the generational gap occurrence (Figure 8).
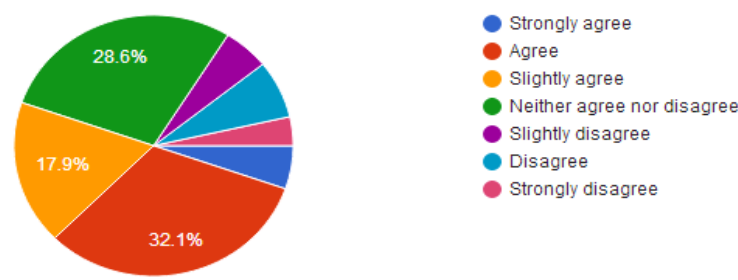

Figure 7.Generation gap tends to develop into a major social problem

Source: Authors' own research results. 


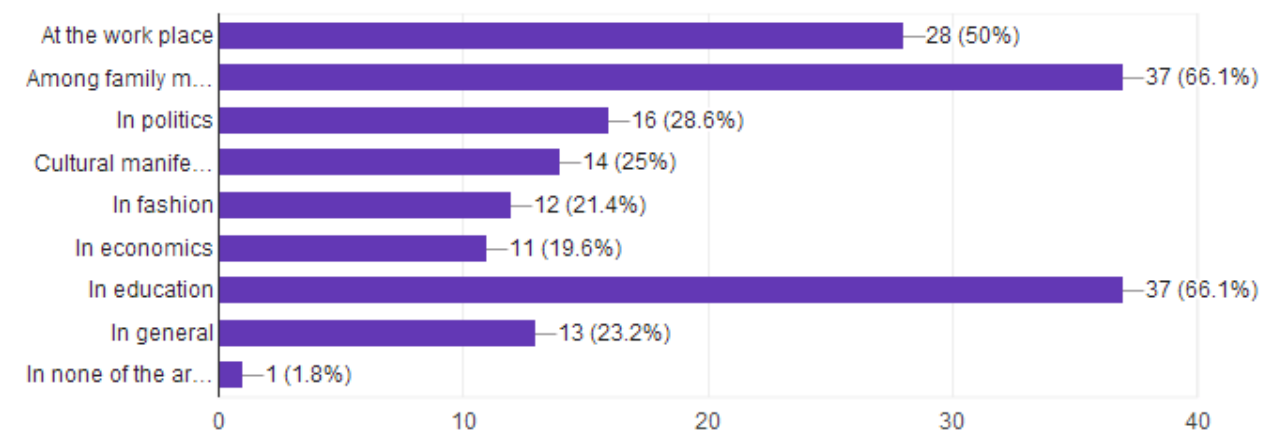

PICBE $\mid 838$

Figure 8. Main areas where the generation gap frequently occurs

Source: Authors' own research results.

Related to the possible actions to be undertaken for diminishing the generational gap, the majority of respondents agreed on the necessity of enhancing the dialog between generations (60.7\%), implementing projects, case studies, guides of good practices (training), and organizing meetings or debates between the parties involved in the conflicts (Figure 9).

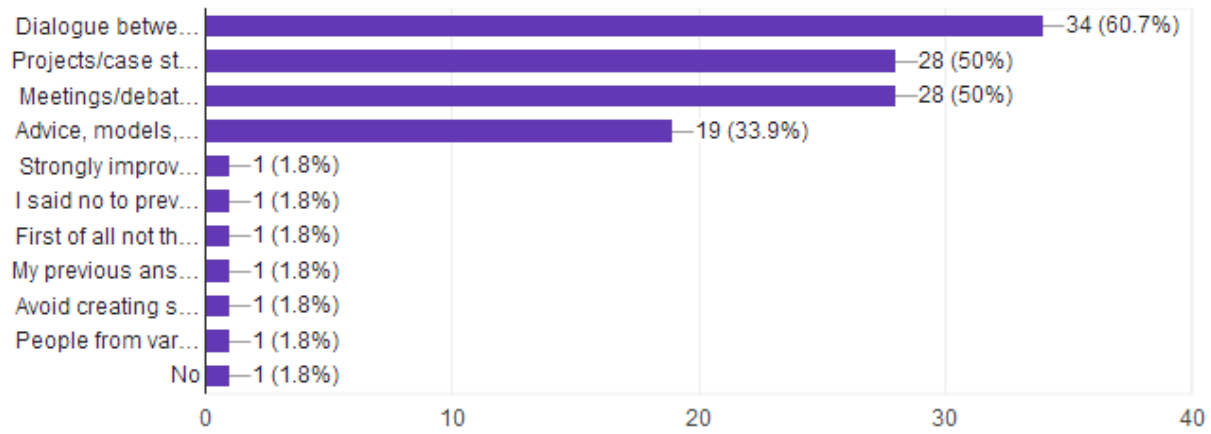

Figure 9. Actions to undertake for diminishing the intergenerational gap

Source: Authors' own research results.

As there is the assumption traditionally embedded in the collective thinking according to which the bigger the age difference, the larger the generational gap, the present study aimed to investigate this assumption (Figure 10). As a result, $62.4 \%$ of the respondents consider it to be true, while $23.2 \%$ had no definitive opinion, and the remaining $14.4 \%$ rejected the assumption. A more in-depth analysis revealed that Generation $\mathrm{X}$ tended to be more in favor of the existence of the correlation between age difference and generational gap as their answers represented $54.3 \%$ out of the total positive answers, and that Generation $\mathrm{Y}$ was not particularly in agreement with the existence of a correlation (only $37.1 \%$ of the positive answers). This result points towards the fact that the intergenerational conflict might be more pronounced between two adjacent generations in comparison to generations that are further apart.
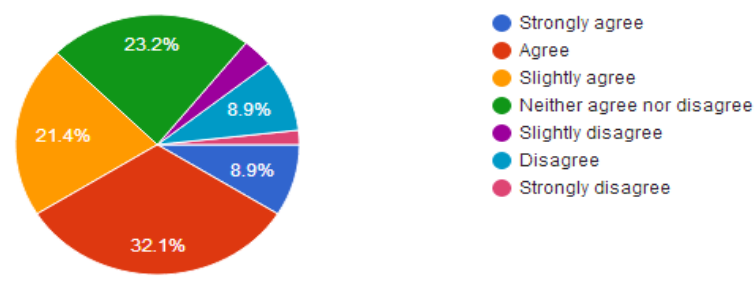

Figure 10. The correlation between age difference and generational conflicts

Source: Authors' own research results. 
As shown in Table 3, Baby Boomers and Generation X were mostly in agreement with the fact that the intergenerational gap affects business sustainability, while in the case of Generation $Y$, there was a larger diversity of opinions, with 13 respondents agreeing and 10 respondents being either neutral or in disagreement.

Table 3. Intergenerational gap and business sustainability

\begin{tabular}{|c|c|c|c|c|c|c|c|}
\hline $\begin{array}{l}\text { Generation/ } \\
\text { Response }\end{array}$ & $\begin{array}{l}\text { Strongly } \\
\text { Agree }\end{array}$ & Agree & $\begin{array}{l}\text { Slightly } \\
\text { Agree }\end{array}$ & Neutral & $\begin{array}{l}\text { Slightly } \\
\text { Disagree }\end{array}$ & Disagree & $\begin{array}{l}\text { Strongly } \\
\text { Disagree }\end{array}$ \\
\hline Baby Boomers & 1 & 2 & 0 & 0 & 0 & 0 & 0 \\
\hline $\mathrm{X}$ & 2 & 10 & 7 & 7 & 1 & 3 & 0 \\
\hline$Y$ & 2 & 6 & 5 & 6 & 1 & 2 & 1 \\
\hline Total & 5 & 18 & 12 & 13 & 2 & 5 & 1 \\
\hline
\end{tabular}

In regards to the HR aspects that businesses should reconsider in order to manage more effectively the dynamics between generations, the respondents mentioned the trainings provided to the employees (55.4\%), the communication strategy $(55.4 \%)$, work-life balance programs (46.4\%), the hiring process $(35.7 \%)$ and flexible schedules (32.1\%). As shown in Figure 11, respondents did not consider that the remuneration system requires changes (only $17.9 \%$ of positive answers).

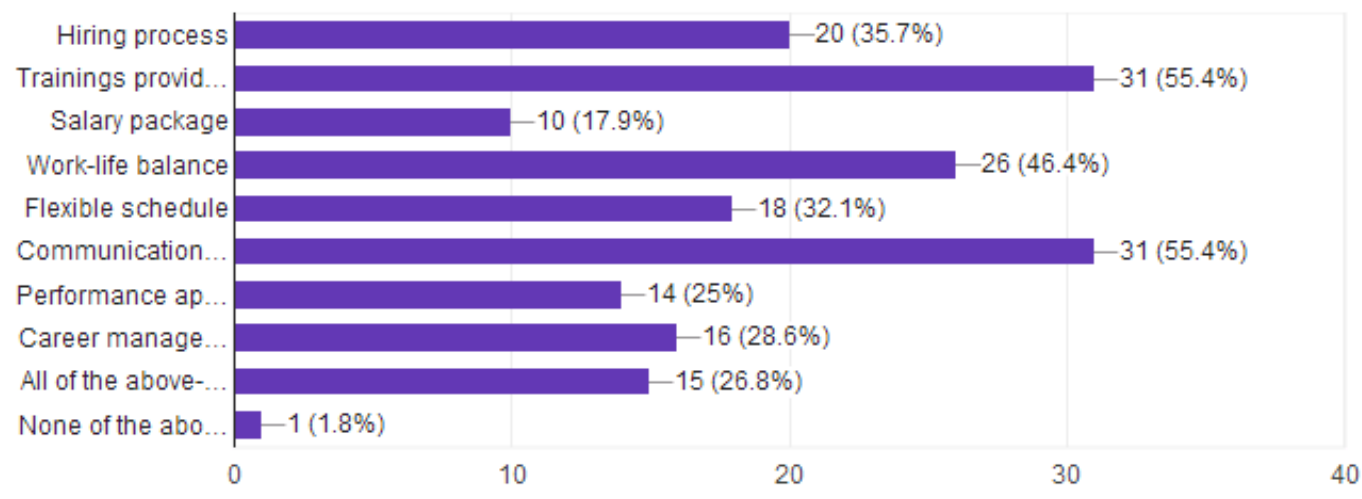

Figure 11. HR aspects to reconsider for better intergenerational dynamics

Source: Authors' own research results.

When asked whether companies should focus more on the respondents' generation when setting up their HR strategies, the respondents from Generation $Y$ were the ones that appeared most in favor of this, as $56.5 \%$ of the Y respondents agree with the statement, compared with $46.7 \%$ of the Generation X respondents and $33.3 \%$ respondents from the Baby Boomer Generation. Thus, Generation Y appears to be the most egocentric generation (see Table 4).

Table 4. Egocentrism in regards to HR strategies

\begin{tabular}{|c|c|c|c|c|c|c|c|}
\hline $\begin{array}{l}\text { Generation/Re } \\
\text { sponse }\end{array}$ & $\begin{array}{l}\text { Strongly } \\
\text { Agree }\end{array}$ & Agree & $\begin{array}{c}\text { Slightly } \\
\text { Agree }\end{array}$ & Neutral & $\begin{array}{l}\text { Slightly } \\
\text { Disagree }\end{array}$ & Disagree & $\begin{array}{l}\text { Strongly } \\
\text { Disagree }\end{array}$ \\
\hline Baby Boomers & & 1 & & 2 & & & \\
\hline $\mathrm{X}$ & 2 & 9 & 3 & 11 & 2 & 2 & 1 \\
\hline $\mathrm{Y}$ & 4 & 6 & 3 & 8 & & 2 & \\
\hline Total & 6 & 16 & 6 & 21 & 2 & 4 & 1 \\
\hline
\end{tabular}

Source: Authors' own research results. 
Finally, when asked whether companies should give equal consideration to all generations when designing their HR strategies, most of the respondents agreed that this would be the preferable scenario. As shown in Table 5, all Baby Boomers agreed to equally consider all the generations in the workplace when setting HR strategies, followed by $83.3 \%$ respondents out of the Generation $\mathrm{X}$ and $82.6 \%$ respondents from Generation Y. Although there were respondents that agreed with both questions related to the importance that should be given to the generations when designing HR strategies, we consider that the differences in the answers were caused by the way in which the questions were formulated.

Table 5. Egalitarianism in regards to HR strategies

\begin{tabular}{|c|c|c|c|c|c|c|c|}
\hline $\begin{array}{l}\text { Generation/Re } \\
\text { sponse }\end{array}$ & $\begin{array}{l}\text { Strongly } \\
\text { Agree }\end{array}$ & Agree & $\begin{array}{c}\text { Slightly } \\
\text { Agree }\end{array}$ & Neutral & $\begin{array}{c}\text { Slightly } \\
\text { Disagree }\end{array}$ & Disagree & $\begin{array}{l}\text { Strongly } \\
\text { Disagree }\end{array}$ \\
\hline Baby Boomers & & 2 & 1 & 0 & 0 & 0 & 0 \\
\hline $\mathrm{X}$ & 11 & 8 & 6 & 2 & 1 & 2 & 0 \\
\hline$Y$ & 4 & 9 & 6 & 2 & 2 & 0 & 0 \\
\hline Total & 15 & 19 & 13 & 4 & 3 & 2 & 0 \\
\hline
\end{tabular}

Source: Authors' own research results.

\section{Conclusions}

Managing the often clashing views and needs of the generations is a real challenge for the organizations composed of a diverse workforce, from Baby Boomers to Generation X and the controverter Millennials. The tension between the older, highly experienced generations, some of whom may be approaching retirement, and the ambitious and talented Millennials who are by far the most tech-savvy and flexible generation, has been a matter of intense discussion ever since they started entering the workforce. What scholars agree upon is that the reality of multi-generational business challenges and alters communication inside and outside the organization, seniority and employees engagement, in a word, the traditional way of conducting business. This is especially true when intergeneration conflicts go overlooked and unaddressed, which is often the case. If we look at the historical succession of generations revealed by the generational theory and extended to be valid for all places and times by generational dynamics, the above phrase seems to be nothing but a cliché. However, it is an evergreen cliché that requires comprehensive understanding and humility from leaders, because as Sterman (2002, p. 501) argues, "we are not only failing to solve the persistent problems we face, but are in fact causing them."

Our research shows that employees prefer HR strategies which take into considerations generations as a whole and this brings us to the conclusion that it might be better for companies to reconsider their preferences for programs targeted at particular generations, e.g. "understanding Generation Y". Instead we propose a more inclusive approach which results from the mixing and matching of generations programs. This is in line with the findings of the main practices that ensure the success of multigenerational companies: a) increased competition for talent; b) more generations working in mixed groups; c) and a clearer relation between productivity and the working environment (AARP, 2007).

We consider that approaches which are focused on the prioritization of the needs and desires of the Millennials, a common trend among companies at the moment, would only accentuate the already existing generational conflicts. Thus, in the context of an impressive number of companies spending their resources to understand the Millennial workforce, we propose at least a more inclusive work environment in which all 
employees are valued, rewarded and helped to grow, if not an HR approach centred on each individual's needs and expectations. This is also the perspective of the HR Director from Orange Romania, Luiza Muller: "We do not expect to be easy, she said, but we find it as being the only feasible solution on the long run, as the intergenerational gap is not a problem per se - there have always been conflicts between generations. We do not want to deeper into the generational dispute, so that we prefer to work harder in order to better understand each and every employee that we have, and not to treat them as being just parts of some classes of people".

\section{References}

AARP (2007), Leading a Multigenerational Workforce

Armour, S. (2005), “Gen Y: They've arrived at Work with a New Attitude”, USA Today, November 6, 2005

Avolio, B.J., Gardner, W.L. (2005), "Authentic leadership development: getting to the root of positive forms of leadership", The Leadership Quarterly, 16, 315-338, Elsevier.

Barrett, R. (2014), Evolutionary coaching, A values-based approach to unleashing human potential, Lulu Publishing House

Birkman (n.d.), How Do Generational Differences Impact Organizations and Teams? Part 1, in Birkman. Reaching further retrieved at http://brandmanvirtualteam1.weebly.com/uploads/7/5/8/7/7587559/generati onal_differences_article_706.pdf [accessed at March 5, 2018].

Howe, N., Strauss, W. (2007), “The next 20 years: How customer and workforce attitudes will evolve", Harvard Business Review, pp.41-52.

Kavros, P.M., Berger, L. (2014), Intergenerational communication in the workplace, $23^{\text {rd }}$ GSC SHRM Annual Conference \& Expo, Atlantic City, N.J., retrieved at http://www.lynnberger.com/wp-content/uploads/2016/01/SHRM-InterGenComm-2014-LB.pdf [accessed at March 5, 2018].

Long Standifer, R. (2017), "A study of actual versus perceived generational differences using the social identity approach", Academy of Management Proceedings, Vol. 2017, No. 1, 12057.

McKenna, E., Beech, N. (2002), Human Resource Management. A concise analysis, Prentice Hall, Pearson Education.

McLoughlin, W.G. (1978), "Revivals, Awakenings, and Reform", The University of Chicago Press, Chicago and London, edited by Martin E. Marty, retrieved at https://books.google.ro/books?id=C9uLMCJQzFEC\&printsec=frontcover\&hl=ro\# $\mathrm{v}=$ onepage $\& \mathrm{q} \& \mathrm{f}=$ false.

Mihalevich, I., Powell, R. and Logan, C. (2017), "Is behavioural flexibility evidence of cognitive complexity? How evolution can inform comparative cognition", Interface Focus, Vol. 7, No. 3, 20160121.

Pagar, S.B., Pimparkar, K.V., Patil, N., Phadtare, A. and Kulkarni, P. (2017), “Decoding the pillars of human intelligence", Journal of Emerging Technologies and Innovative Research, Vol. 4, No. 12, pp. 624-628.

Popper, M., Mayseless, 0. (2007), The building blocks of leader development: a psychological conceptual framework, University of Haifa, Department of Psychology.

Raines, C., Ewing, L. (2006), The Art of Connecting, American Management Association.

Scheef, D., Thielfoldt, D., (n.d.) "Engaging Multiple Generations among Your Workforce" retrieved at 
http://www.keepem.com/pdf/Engaging\%20Multiple\%20Generations\%20amon g\%20Your\%20Workforce.pdf, [accessed at March 5, 2018].

Society for Human Resource Management, 2011, Intergenerational Conflict in the Workplace.

STERMAN, J. D. (2002) All Models are Wrong: Reflections on Becoming a Systems Scientist. System Dynamics Review, 18, 501-531. http://scripts.mit.edu/ jsterman/On-Line_Publications.html\#2002All

Wallace, A. F.C. (1956), "Revitalization Movements: Some Theoretical Considerations for Their Comparative Study", American Anthropologist, 58:264-81.

Wongupparaj, P., Wongupparaj, R., Kumari, V. and Morris, R.G. (2017), "The Flynn effect for verbal and visuospatial short-term and working memory: A cross-temporal meta-analysis", Intelligence, Vol. 64, pp. 71-80.

www.bls.gov/emp/emplab1.htm

Xenakis, (2010), International business forecasting using system dynamics with generational flows, Computer Sciences Corporation (CSC) paper for LEADING EDGE FORUM, http://generationaldynamics.com/dl/CSC_Papers_2010_Generational_Dynamics. pdf. 